\title{
QTL Mapping to QTL Cloning: Mice to the Rescue
}

\section{Michel Georges}

\author{
Department of Genetics, Faculty of Veterinary Medicine, University of Liége, 4000-Liége, Belgium
}

W ith the availability of dense, highly informative marker maps, it has recently become feasible to map genes (Quantitative Trait Loci or QTL) accounting for part of the heritability of continuously distributed traits in experimental crosses as well as outbred populations. QTL mapping efforts have almost invariably revealed a limited number of loci with effects of a magnitude clearly departing from the predictions of the infinitesimal model (a model introduced to facilitate mathematical treatment of quantitative traits rather than to truly reflect their underlying biology). As most experimental designs would have limited detection power, which could lead to an overestimation of the identified gene effects, interpretation of results from QTL mapping studies must be viewed with caution. However, numerous independent confirmation studies leave little doubt that most quantitative traits indeed involve a limited suite of loci with major effect. This assertion seems to hold not only for QTL mapped in crosses between divergent lines, butmore importantly_for QTL segregating in outbred populations as well (for review, see Paterson 1995).

Despite the sometimes unexpected magnitude of the identified QTL effects, the lack of simple correspondence between genotype and phenotype in complex trait analysis precludes the unambiguous identification of recombinant individuals. This may limit the achievable mapping resolution of QTL, posing a serious threat to the efficacy of positional (candidate) cloning for QTL considerably. QTL mapping efforts, whether performed in pedigrees or by exploiting linkage disequilibrium, are likely to leave geneticists with a portion of the genome that contains tens if not hundreds of genes and many DNA sequence polymorphisms to examine to identify the causal variant. Mutations causing monogenic inherited diseases are often destructive enough to leave little doubt about their causality. Even if the functional consequences of such mutations were less transparent, demonstration of a perfect correspondence between genotype and phenotype strongly implicates the corresponding gene, if not mutation. In the case of quantitative inheritance, the ambiguous genotypephenotype relationship, as well as the possibly more subtle nature of the causal mutations, may complicate considerably the distinction between neutral and causative polymorphisms in the candidate region.

Imaginative geneticists will certainly find a number of strategies to untangle this Gordian knot (e.g., Risch and Merikangas 1996). Increasingly, however, rodent models appear potentially to be one of the most valuable assets in QTL quests. This is illustrated vividly in an article by $\mathrm{Hu}$ and colleagues, dealing with comparative QTL mapping for Salmonella resistance in species as distantly related as mice and chicken ( $\mathrm{Hu}$ et al., this issue)

It is well established that genes contribute to individual differences in resistance to a variety of viral, bacterial, and parasitic pathogens (for review, see Malo and Skamene 1994; Hill 1996). A striking example of a monogenic disease re sistance in man is the virtual immunity to HIV infection of individuals homozygous for a deletion in the CCR5 receptor (Liu et al. 1996; Samson et al. 1996). Genetic control of host resistance to infection is often more complex, however, and thought to involve multiple genes.

This is, for instance, the case when studying resistance to Salmonella in poultry. In backcrosses obtained from susceptible and resistant chicken lines, survival time after inoculation behaves very much as a quantitative trait, suggesting the contribution of several QTL (Hu et al., this issue). The importance of Salmonella contamination of poultry products as a cause of food-borne disease in humans amply justifies efforts to identify the underlying QTL, which could lead to more efficient control strategies.

Genetic resistance to Salmonella infection is also well documented in mice and it is known to be a multifactorial entity as well. However, judicious strain choice and refinement of the phenotype has allowed the dissection of murine resistance/susceptibility to Salmonella in a series of distinct entities, each segregating as simple Mendelian traits in specific matings (for review, see Malo and Skamene 1994). Two of these in particular have been the subject of considerable attention: Lps and Bcg.

Measuring LPS (lipopolysaccharide, a major component of the outer membrane of Gram-negative bacteria)-induced spleen cell proliferation or liver CFU counts after inoculation with Salmonella in (resistant $\times \mathrm{C} 3 \mathrm{H} / \mathrm{HeJ}) \mathrm{F}_{1}$ $\times \mathrm{C} 3 \mathrm{H} / \mathrm{HeJ}$ backcrosses, reveals two nonoverlapping populations. This was interpreted as evidence for the segregation of a locus, Lps, with major effect on responsiveness to LPS and, concomitantly, regulation of preimmune susceptibility to infection with Gram-negative bacteria, including Salmonella. Using $>1000$ backcross individuals, the proposed Lps locus has been mapped recently to sub-centimorgan resolution on mouse chromosome 4 (Qureshi et al. 1996). Although the actual Lps gene has not been identified yet, it seems reasonable to anticipate its succesful positional cloning in the not-too-distant future.

In a similar approach, using spleen CFU counts after infection with Mycobacterium bovis (BCG) as a discrete phenotype in 1000 (C57L/J × C57BL/ 6) $\mathrm{F}_{1} \times \mathrm{C}$ 57BL/6J backcross progeny, the Bcg locus was mapped by linkage analysis to a 0.3-cM interval on mouse chromosome 1 (Malo et al. 1993). The Bcg locus (also known as Ity or Lsh) modulates the capacity of macrophages 


\section{Insight/Outlook}

to restrict the growth of ingested pathogens as diverse as Mycobacteria, Salmonella, and Leishmania, and, therefore, the proliferation of these agents in the reticuloendothelial organs during the preimmune phase. In a perfect illustration of the positional cloning strategy, Vidal et al. (1993) isolated the Nramp1 gene as a strong candidate from the region based on its macrophage-restricted expression pattern and a nonconservative Gly-Asp substitution in susceptible mice, which lead to complete absence of the protein in their macrophages. The precise mode of action of Nrampl, an integral membrane phosphoglycoprotein resembling known prokaryotic and eukaryotic transport proteins, remains unknown. Subsequent demonstration that Nrampl disruption using knockout technology abrogates natural resistance to infection with intracellular parasites provided the formal proof of the causality of the corresponding gene (Vidal et al. 1995).

Pursuing the prediction of Malo and Skamene (1994) that loci contributing to multifactorial resistance to infectious agents identified in mice would be prime candidates for QTL affecting resistance/susceptibility in other species, $\mathrm{Hu}$ et al. (this issue) tested the contribution of the Bcg and Lps orthologs with Salmonella resistance variation observed in chicken lines. The entire coding region of the $\mathrm{N} \mathrm{rampl}$ gene was sequenced from three resistant (including W1) and three susceptible chicken lines. Apart from 10 apparently neutral nucleotide substitutions, Hu et al. found a nonconservative Arg-GIn substitution in a highly conserved portion of the fifth transmembrane domain, confined to one of the susceptible lines: $C$. They found a clear association ( $P=0.0004)$ between the corresponding mutation and survival rate at day 7 post infection in 425 $(\mathrm{W} 1 \times \mathrm{C}) \mathrm{F}_{1} \times \mathrm{C}$ backcross progeny. Nrampl CC homozygous chicken had a mortality rate twice as high as their CW 1 contemporaries ( $27 \%$ vs. $13 \%$ ). Altogether, these data suggest very strongly a direct role of Nrampl in susceptibility to Salmonella infection in chicken.

To test the effect on Salmonella resistance of the Lps ortholog in chicken in the absence of the actual gene, Malo and Skamene (1994) generated a restriction fragment-length polymorphism (RFLP) marker using a human tenascin C (TNC)
CDNA probe. In mice, the TNC gene is located at $0.7 \mathrm{cM}$ from the Lps locus. The TNC probe revealed alternate alleles in the resistant $\mathrm{W} 1$ and susceptible $C$ lines, which allowed them to trace the segregation of the corresponding chromosome segment-shown to be independent of that of the NRAMP1 locus-in the same 452 backcross progeny. Again, there was a significant $(P=0.005)$ association with survival rate: The mortality of CC homozygotes was nearly twice that of CW1 individuals at day 7 post infection. Although the conservation of synteny be tween mice and chicken around the Lps locus still needs verification, these data are indicative of a causal role of the Lps locus in these chicken lines.

With this work, Hu et al. (this issue) demonstrate how judicious use of comparative mapping data can, at least in specific instances, accelerate identification of QTL even in species where the available genomic tools are modest compared to those in humans and mice (Georges and Anderson 1996). The generic value of this approach, however, remains to be demonstrated and will de pend on the degree of overlap between the suites of QTL underlying the genetic variation for a given trait in different species. This degree of QTL convergence will reflect how far different sets of genes may lead to the same phenotype. Comparative QTL mapping is therefore a potentially powerful approach to address this fundamental issue in developmental biology.

The most extensive comparative data set available at this point probably comes from QTL mapping efforts in plants. Interestingly, an unexpectedly high proportion of QTL affecting seed size, height, flowering, and other complex traits do correspond among different taxa (for review, see Paterson 1995).

Significant interspecies overlap between QTL suites has the potential to play a crucial role in efforts aimed at cloning QTL, particularly in domestic animal species. Indeed, whereas QTL cloning still faces major conceptual hurdles in most outbred species for the reasons mentioned above, mouse as a model organism offers the necessary tools to make QTL cloning an achievable objective in many circumstances: Large numbers of offspring can be generated from selected matings at moderate cost; animals can be reared in wellcontrolled environmental conditions; tools for genomic analysis are particularly well developed and will continue to improve at a much faster rate than in any other mammal except man; andlast but not least-a panoply of powerful transgenic and gene targeting methods is available to perform the ultimate functional tests.

QTL mapping could be performed in parallel in mice and livestock for traits of interest. Numerous selection lines are already available in mice for traits that are of relevance to agriculture. Not only would this allow the rigorous evaluation of the degree of interspecies QTL overlap, but positional cloning could readily be initiated in mice for QTL yiel ding evidence for interspecies conservation based on primary QTL mapping data. Once a QTL affecting a trait of interest is cloned in mice, extensive mutation screening could be performed for the ortholog in the domestic species of interest and its contribution to genetic variation examined using adequate association tests, including the transmission/ disequilibrium test (Spielman et al. 1993). One could easily justify pursuing QTL mapped in micealone, not only because of the fundamental interest in identifying a gene underlying a complex trait of interest, but because association studies based on the knowledge of the underlying gene have the potential to be more powerful for identifying segregating QTL than conventional linkage mapping (Risch and Merikangas 1996).

The most difficult part of such an exercise may beto convince agencies funding agricultural research of the value of a detour into mouse genomics.

\section{REFERENCES}

Georges, M. and L. Anderson. 1996. Genome Res. 6: 907-921.

Hill, A.V.S. 1996. Curr. Opin. Genet. Dev. 6: 348-353.

Hu, J., N. Bumstead, P. Barrow, G. Sebastiani, L. Olien, K. Morgan, and D. Malo. 1997. Genome Res. (this issue).

Liu, R., et al. 1996. Cell 86: 367-377.

Malo, D. and E. Skamene. 1994. Trends Genet. 10: 365-371.

Malo, D., S.M. Vidal, J. Hu, E. Skamene, and P. Gros. 1993. Genomics 16: 655-663.

Paterson, A.H. 1995. Genome Res. 5: 321-333.

Qureshi, S.T., L. LariviPre, G. Sebastiani, S. Clermont, E. Skameme, P. Gros, and D. Malo. 1996. Genomics 31: 283-294. 
Risch, N. and K. Merikangas. 1996. Science 273: 1516-1517.

Samson, M., F. Libert, B.J. Doranz, J. Rucker, C. Liesnard, C.-M. Farber, S. Saragosti, C. Lapouremoulie, J. Cognaux, C. Forceille, G. Muyldermans, C. Verhofstede, G. Burtonboy, M. Georges, T. Imai, S. Rana, Y. Yi, R.J. Smyth, R.G. Collman, R.W. Doms, G. Vassart, and M. Parmentier. 1996. Nature 382: 722-725.

Spielman, R., R.E. McGinnis, and W.J. Ewens. 1993. Am. J. Hum. Genet. 52: 506.

Vidal, S., D. Malo, K. Vogan, E. Skameme, and P. Gros. 1993. Cell 73: 469-485.

Vidal, S., M.L. Tremblay, G. Govoni, S. Gauthier, G. Sebastiani, D. Malo, E. Skamene, M. Olivier, S. Jothy, and P. Gros. 1995. J. Exp. Med. 182: 655-666. 


\title{
Insight/Outlook
}

\section{The Mappers' Torch Song}

\author{
Jun Yu and Gane K.-S. Wong
}

The Human Genome Center, Department of Medicine, University of Washington, Seattle, Washington 98195 USA

$\mathbf{R}$ Schlessinger at Washington University (Nagaraja et al. 1997), and another led by Eric Green at the National Human Genome Research Institute (Bouffard et al., this issue)-announced the completion of yeast artificial chromosome (YAC)-based sequence-tagged site (STS)content physical maps for human chromosomes $X$ and 7 , respectively. Although we understand why most of the world is seeking alternatives to the many years of laborious work involved in building such maps, we feel that pre cisely because maps of such high quality are so rare, their completion should be cel ebrated. As these an nouncements signal the symbolic "passing of the torch" from mapping to sequencing, it is timely to reflect on what has been accomplished and on what lies ahead for the Human Genome Project (Watson 1990; Collins and Galas 1993).

A number of factors distinguish these two maps from others that have been published previously (Foote et al. 1992;
Ashworth et al. 1995; Bell et al. 1995; Chumakov et al. 1995; Collins et al. 1995; Crollius et al. 1996; Doggett et al. 1995; Hudson et al. 1995; Krauter et al. 1995; Quackenbush et al. 1995; Qin et al. 1996): First, the significant size of chromosomes $X$ and 7 is estimated at 160 and $170 \mathrm{Mb}$, respectively; the next largest chromosome-specific map, for chromosome 11, is $130 \mathrm{Mb}$. Second, the high density of STS markers on these maps averages $80 \mathrm{~kb}$ in both cases, which is better than the $100 \mathrm{~kb}$ goal set by the Human Genome Project and comparable to the best of the chromosome-specific maps (e.g., chromosomes 11 and 22). Third, these chromosome maps contain a high fraction of uniquely ordered STSs, which is $90 \%$ on the chromosome 7 map and often not even specified on the other maps. Fourth, well-characterized and stable YAC clones (a few thousand in number for each map) are used in the contig construction; for example, hybrid cellderived chromosome 7 YACs exhibited $<15 \%$ rearrangements, compared with
$50 \%$ for Centre d'Etude du Polymorphisme Humain (CEPH) mega-YACs al ong the same chromosome. And, fifth, there is complete integration of the STS maps with the existing radiation hybrid and genetic maps. Other STS mappers have achieved or, in some cases, exceeded some of these goals, but so far none except Nagaraja et al. (1997) and Bouffard et al. (this issue) has accomplished all of these goals.

It is the high quality of these two maps that makes them stand out and bring to issue the basic question of what it means to say that a map (and now, increasingly, a sequence) is "finished." There is not a product in the world that cannot be made a little cheaper or finished a little sooner if the quality is allowed to slip. However, if we are to use a race track analogy, the race that we are engaged in is a relay, not an individual event; the success of the endeavor will be judged by the accomplishments of the entire team. Consider, then, the overall consequences of having a better map. The most significant parameter is

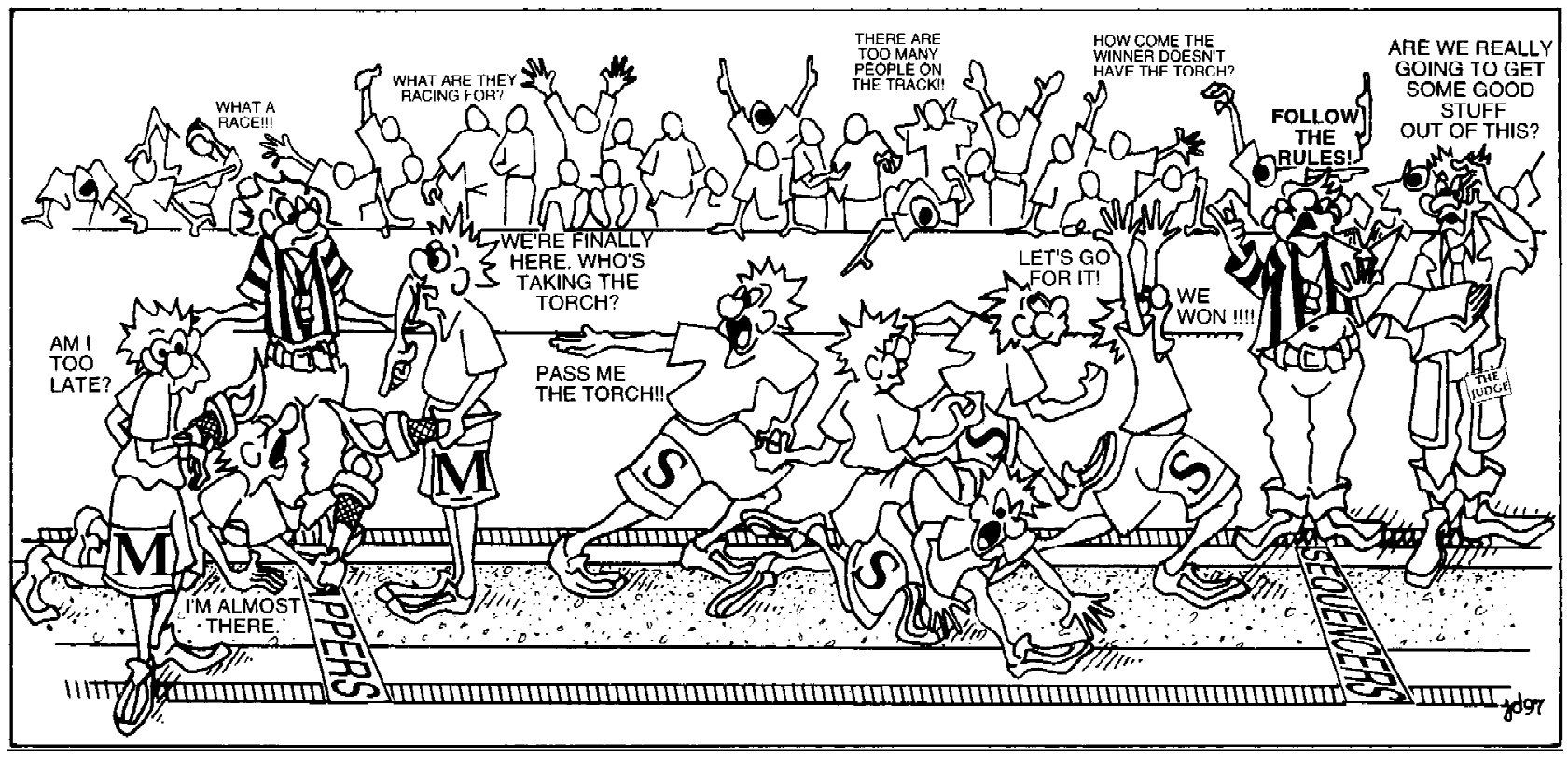


not the average distance between adjacent STSs but, rather, the average distance between uniquely ordered STSs (Olson and Green 1993; Cox et al. 1994). In the chromosome 7 map, these distances are $80 \mathrm{~kb}$ between adjacent STSs and $90 \mathrm{~kb}$ between uniquely ordered STSs. In contrast, although the map of Hudson et al. (1995) covers the entire human genome (providing its own unique advantages), the average distance between adjacent STSs is only 170 $\mathrm{kb}$ and the average distance between uniquely ordered STSs is estimated to be five times larger-or just under $1 \mathrm{Mb}$. STS-content maps are currently used to screen bacterial artificial chromosome (BAC) or P1-derived artificial chromosome (PAC) libraries with average insert sizes of 140 kb (Shizuya et al. 1992; Ioannou et al. 1994; Kim et al. 1996). When the clone insert sizes are smaller than the distance between uniquely ordered STSs, gaps become the rule rather than the exception, and significant amounts of chromosome walking are usually needed to close the gaps. Even if the costs for generating the new STSs and rescreening the libraries can be subsumed into the much larger costs for sequencing, the true costs for mapping end up being hidden as sequencing costs. So what does it mean to "finish" a map if, in the end, it has to be rebuilt by the sequencers?

As one example, take the work being done at the University of Washington Genome Center, where a significant fraction of the sequencing has been on chromosome 7. Having access to the map of Bouffard et al. (this issue) has proven quite fortunate. Use of the multiple complete digest (MCD) restriction fragment mapping technique (Wong et al. 1997) generated close to $2 \mathrm{Mb}$ of contiguous sequence-ready cosmids. To guard against YAC rearrangements, every region was validated by two independently mapped YACs. Given the accuracy of the MCD maps, this meant that the sequenced materials were validated to an average resolution of $200 \mathrm{bp}$, far better than in the original STSmap. A dozen YACs were subcloned into cosmids and MCD mapped to generate this $2-\mathrm{Mb}$ region. No errors were found in the ordering of the YACS on the STS map, and only one of the YACs exhibited a rearrangement-one that was too small to have been detected by the STS map. These YACs were also MCD vali- dated against more than a dozen BACs (J. Yu and G.K.-S. Wong, unpubl.). The point here is not to extol the virtues of YACs or to advocate any particular method for generating a high-resolution sequence-ready map from an STScontent map. Rather, it is to affirm the very high quality of the chromosome 7 map. Similarly positive experiences with the chromosome 7 map have been re ported at the Genome Center at Washington University, using another fingerprint-based high-resolution mapping technique (R. Waterston, pers. comm.). It is also worth noting that a wellhandled YAC library can be used as a sequencing substrate. This is particularly important, as having the flexibility to choose among a wide variety of cloning systems is essential for closure. For example, $20 \%$ of the nematode genome is not clonable in cosmids (Coulson et al. 1991), and work is currently under way to close these regions by shotgun sequencing directly from YACs (R. Waterston, pers. comm.).

As we gaze longingly at the still distant finish line, thoughts turn to the other chromosomes, where the STSs may not be as well ordered and where a high-quality large-insert clone library has yet to be mapped. The final phase of the Human Genome Project-the actual sequencing of those 3 billion base pairs-hinges on this point. We are not arguing against a continuous improvement in the STS maps as a part of any sequencing effort. BACs and PACs are emerging as the large-insert clones of choice, and these new libraries have to be placed on the maps. However, in this mad dash toward the finish line, we would caution against taking too cavalier an attitude toward data quality, particularly with regard to theissue of clone validation. STS mapping technology cannot detect clonal aberrations that are smaller than the distance between uniquely ordered STSs. Small insertions or del etions of just a few kilobases in size are possible. We would be remiss in our duties if we did not point out the following simple fact: Any problems that we choose to "sweep under the rug" will only come back to haunt the biologists who will be using our data-the people to whom the Human Genome Project chromosome mappers and sequencers will be "passing the torch." It is because of the demonstrated high quality of the chromosomes $X$ and 7 maps that we, the immediate users of the maps, are grateful. Let us strive to ensure that the ultimate users of the sequence data being produced by the Human Genome Project will feel likewise in the years to come.

\section{REFERENCES}

Ashworth, L.K., M.A. Batzer, B. Brandriff, E. Branscomb, P. de Jong, E. Garcia, J.A. Garnes, L.A. Gordon, J.E. Lamerdin, G. Lennon et al. 1995. Nature Genet. 11: 422-427.

Bell, C.J., M.L. Budarf, B.W. Nieuwenhuijsen, B.L. Barnoski, K.H. Buetow, K. Campbell, A. Colbert, J. Collins, P.R. Desjardins, D. DeZwaawn et al. 1995. Hum. Mol. Genet. 4: 59-69.

Bouffard, G.G., J.R. Idol, V.V. Braden, L.M. Iyer, A.F. Cunningham, L.A. Weintraub, J.W. Touchman, R.M. Mohr-Tidwell, D.C. Peluson, R.S. Fulton et al. 1997. Genome Res. (this issue).

Chumakov, I.M., P. Rigault, I. LeGall, C. Bellann'e-Chantelot, A. Billault, S. Guillou, G. Guasconi, E. Poullier, I. Gros et al. 1995. Nature 377: 175S-197S.

Collins, F. and D. Galas. 1993. Science 262: 43-46.

Collins, J.E., C.G. Cole, L.J. Smink, C.L. Garrett, M.A. Leversha, C.A. Soderlund, G.L. Maslen, L.A. Everett, K.M. Rice, A.J. Coffey et al. 1995. Nature 377: 367S-379S.

Cox, D.R., E.D. Green, E.S. Lander, D. Cohen, and R.M. Myers. 1994. Science 265: 20312032.

Coulson, A., Y. Kozono, B. Lutterbach, R. Shownkeen, J. Sulston, and R. Waterston. 1991. BioEssays 13: 413-417.

Crollius, H.R., M.T. Ross, A. Grigoriev, C.J. Knight, E. Holloway, J. Misfud, K. Li, M. Playford, S.G. Gregory, S.J. Humphray et al. 1996. Genome Res. 6: 943-955.

Doggett, N.A., L.A. Goodwin, J.G. Tesmer, L.J. Meincke, D.C. Bruce, L.M. Clark, M.R. Altherr, A.A. Ford, H.C. Chi, B.L. Marrone et al. 1995. Nature 377: 335S-366S.

Foote, S., D. Vollrath, A. Hilton, and D.C. Page. 1992. Science 258: 60-66.

Hudson, T.J., L.D. Stein, D.S. Gerety, J. Ma, A.B. Castle, J. Silva, D.K. Slonim, R. Baptista, L. Kruglyak, S.H. Xu et al. 1995. Science 270: 1945-1954.

Ioannou, P.A., C.T. Amemiya, J. Garnes, P.M. 


\section{Insight/Outlook}

Kroisel, H. Shizuya, C. Chen, M.A. Batzer, P.J . de Jong. 1994. Nature Genet. 6: 84-89.

Kim, U.J., H. Shizuya, H.L. Kang, S.S. Choi, C.L. Garret, L.J. Smink, B.W. Birren, J.R. Korenberg, I. Dunham, M.I. Simon et al. 1996. Proc. Natl. Acad. Sci. 93: 6297-6301.

Krauter, K., K. Montgomery, S.-J. Yoon, J. LeBlanc-Straceski, B. Renault, I. Marondel, V. Herdman, L. Cupelli, A. Banks, J. Lieman et al. 1995. Nature 377: 321S-333S.

Nagaraja, R., S. MacMillan, J. Kere, C. Jones, S. Griffin, M. Schmatz, J. Terrell, M. Shomaker, C. Jermak, C. Hott et al. 1997. Genome Res. 7: $210-222$

Olson, M.V. and P. Green. 1993. Cold Spring Harbor Symp. Quant. Biol. 58: 349-355.

Qin, S., N.J. Nowak, J. Zhang, S.N.J. Sait, P.G. Mayers, M.J. Higgins, Y. Cheng, L. Li, D.J. Munroe, D.S. Gerhard et al. 1996. Proc. Natl. Acad. Sci. 93: 8034-8038.

Quackenbush, J., C. Davies, J.M. Bailis, J.V. Khristich, K. Diggle, Y. Marchunk, J. Tobin, S.P. Clark, A. Rodkins, S. Marceno et al. 1995. Genomics 29: 512-525.

Shizuya, H., B. Birren, U.J. Kim, V. Mancino, and T. Splepak. 1992. Proc. Natl. Acad. Sci. 89: 8794-8797.

Watson, J.D. 1990. Science 248: 44-49.

Wong, G.K.-S., J. Yu, E.D. Thayer, and M.V. Olson. 1997. Proc. Natl. Acad. Sci. 94: 55255230. 


\title{
From Bench to Bedside.... But When?
}

\author{
Charis Eng ${ }^{1}$ \\ Department of Adult Oncology, Human Cancer Genetics Unit, Program in Population Sciences, Dana-Farber Cancer Institute, \\ Harvard Medical School, Boston, Massachusetts, USA and Cancer Research Campaign, Human Cancer Genetics Research \\ Group, University of Cambridge, Cambridge, UK
}

But mousy, thou art no' thy 'lane

In proving foresight might be vain

The best laid schemes o' mice and men gang aft agley

And leave us nought but grief and pain

For promised joy

Robert Burns

rior to September 1994, we physicians in Cancer Family Clinic sat in front of patients who had family histories of breast cancer, prophesying, al beit cautiously, that we would be practicing clinical cancer genetics differently once the first breast cancer susceptibility gene, BRCA 1 was cloned. In the autumn of 1994, BRCA1 was delivered into an expectant world of scientists, clinical cancer geneticists, patients, and curious onlookers (Miki et al. 1994). In rapid succession, thanks to the Human $\mathrm{Ge}$ nome Project and its fallout technology and information, the second breast cancer susceptiblity gene BRCA2 was mapped and isolated (Wooster et al. 1994, 1995); other genes that may lend susceptiblity to breast cancer, ATM (ataxia-telangiectasia) and PTEN (Cowden syndrome), ensued (Savitsky et al. 1995; Nelen et al. 1996; Liaw et al. 1997). The era of molecular oncology had arrived.

But what makes cutting-edge genetic findings of today clinical practice tomorrow? The most important criterion is benefit or potential benefit to the patient-that genetic tests result in altered clinical management. Other criteria (Table 1) include ease of mutation detection, the majority of people with a specific inherited cancer syndrome contain mutations within the same gene, the mutation analysis allows prediction of cancer risk, and effective surveillance or effective prophylactic procedures are available. Two inherited cancer syndromes illustrate the agony and ecstasy-apologies to Michelangelo-of translating the latest molecular genetic findings into clinical practice: the hereditary breast cancer (HBC) syndromes and multiple endocrine neoplasia type 2 (MEN 2). As highlighted in a Lancet Grand Round convened at the Royal Marsden Hospital, Sutton, UK (Eng et al. 1994), the differences between these syndromes were obvious even before the identification of BRCA 1 .

\section{The Syndromes: MEN 2 vs. HBC}

MEN 2 is an inherited cancer syndrome characterized by medullary thyroid carcinoma (MTC) (the most common fatal complication), pheochromocytoma (PC), and hyperparathyroidism (HPT). Depending on the tissues involved and their combination of features, this syndrome is subdivided further into MEN 2A, MEN 2B, and familial medullary thyroid carcinoma (FMTC). Prior to genetic testing, annual biochemical screening for all individuals at risk started at age 6 for MEN $2 A$ and FMTC, and younger for MEN 2B. Like all indirect screening tests, false positives and false negatives occurred.

HBC comprises a group of autosomal dominantly inherited cancer syndromes, including site-specific breast cancer, breast-ovarian cancer syndrome, and site-specific ovarian cancer syndrome. To complicate matters, other HBC syndromes do exist (Table 2), but for purposes of this discussion, only these three will be considered.

\section{Ease of Mutation Detection: RET vs. BRCA1 and BRCA2}

The RET proto-oncogene, encoding a receptor tyrosine kinase, is the susceptibility gene for MEN 2 (Eng 1996). Although RET has 21 exons (Myers et al. 1995), germ-line mutations in only one of eight codons encompassed within five exons have thus far been associated with MEN 2 (Eng et al. 1996). Direct se- quence analysis, differential restriction digestion, single-strand conformation polymorphism (SSCP) with heteroduplex analysis, and denaturing gradient gel electrophoresis (DGGE) are equally accurate and user friendly with a high throughput and reasonable cost (Marsh et al. 1994; Mulligan et al. 1994; Borst et al. 1995; Kambouris et al. 1996).

BRCA 1 and BRCA2 together have a total of 49 exons. Unlike RET in MEN 2, germ-line mutations associated with HBC are scattered along the full length of these genes (Breast Cancer Information Core, http://www.nhgri.nih.gov/ Intramural research/Lab_tran sfer/Bic). Thus, various mutation scanning technologies are employed instead of the gold standard of nucleotide sequencing (Eng and Vijg 1997). The tradeoff of accuracy for high throughput is germane, as the entire discussion about mutation frequency, penetrance, and risk (below) can be obviated if the techniques used in these molecular epidemiologic studies have senstivities or specificities well below $100 \%$. Some may fear, for example, that pure heteroduplex analysis used in the recent study by Couch et al. (1997) has a low sensitivity. However, it is comforting to note that the mutation frequencies obtained in comparablestudies were identical using heteroduplex analysis (Couch et al. 1997) and DGGE (Stoppa-Lyonnet et al. 1997), a technique with virtually $100 \%$ accuracy (Eng and Vijg 1997).

A RET-MEN 2-like situation, however, does exist for HBC in the Ashkenazi Jewish population, a genetically distinct popluation of Jews, whose ancestors lived in central and eastern Europe (for review, see Tonin et al. 1996; Streuewing et al. 1997). Three ancient mutations, c.185delAG and c.5382InsC in BRCA1 and c.6174delT in BRCA2, are commonly found in Ashkenazi HBC families. It is relatively easy to test a panel of these mutations by any detec- 


\section{Insight/Outlook}

tion technique; in the Research MolecuIar Diagnostics Laboratories of the DanaFarber Cancer Institute, these are the only BRCA1 and BRCA2 mutations that are tested.

Although the detection technology choiceisa nonissuein MEN 2, it impacts greatly on HBC genetic testing. Hope fully, in the not too distant future, costefficient mutation scanning of several genes in parallel will help (Eng and Vijg 1997).

\section{Germ-Line Mutation Frequencies in MEN 2 and HBC Susceptibility Genes}

Germ-line mutations in RET occur in $>92 \%$ of all MEN 2 cases (Eng et al. 1996). Res ipsa loquitur (That which is obvious or self-evident). Unlike RET testing in MEN 2, 3 years after BRCA1 isolation and 2 years after BRCA2 cloning-a long time in molecular genetic termswe still sit in front of our HBC patients in Cancer Genetics Clinic, but we most certainly cannot offer them BRCA(X) testing as a routine clinical service.

Initially, based on linkage analysis with $17 q$ markers flanking the BRCA1 locus in "large" families with breast and ovarian cancer, BRCA1 mutations were predicted to account for the majority of HBC families, even as high as $90 \%$ (Easton et al. 1993). Similarly, 50\% of large site-specific breast cancer families appeared to be linked to this locus (Hall et al. 1990; Easton et al. 1993). The key word is large, as the original studies were based on the most obvious families, comprising multigenerational families with many affected individuals. In addition, families with ovarian cancer were sought for those studies because it increased the probability of linkage to 17q. More often than not, these do not represent the patient population in our cancer genetics clinics. More recently, taking "all comers" with familial breast cancer, with or without ovarian cancer, two centers (one in France and the other in the U.S.) found $\sim 15 \%$ had germ-line BRCA1 mutations (Couch et al. 1997; Stoppa-Lyonnet et al. 1997).

Can we predict which families represent the $15 \%$ with germ-line BRCA 1 mutations, raising the possibility of implementing practical genetic testing for these families? The presence of ovarian cancer seems to increase the chances that there is a BRCA 1 mutation (Couch et al. 1997; Stoppa-Lyonnet et al. 1997), bearing out predictions based on linkage, although not to that great an extent. Instead of the $90 \%$ predicted, -40\%-45\% of breast-ovarian cancer families have these mutations. Unlike linkage-based estimates using large families, only $7 \%$ of the clinic families with breast cancer al one carried a BRCA 1 mutation (Couch et al. 1997). Interestingly, the absolute number of family members affected with breast cancer is not independently predictive of the presence of BRCA1 mutation.

Partially reflecting the $2 \%$ prevalence of the three ancient mutations in the Ashkenazi Jewish population, the clinicbased study by Couch et al. (1997) revealed that belonging to the Ashkenazim increased the probability of detecting a germ-line BRCA1 mutation whether one was diagnosed with breast cancer under the age of 40 or belonged to a family with breast cancer only or breast and ovarian cancer ( $26 \%$ overall vs. $16 \%$ entire study).

An equivalent all comers study has yet to be performed for BRCA2, al- though, doubtless, such analyses are in progress. However, extrapolating from the BRCA1 experience, clinical cancer geneticists suspect that the BRCA2 figures will also be lower.

Overall, unlike MEN 2, HBC is genetically heterogeneous. Thus, more predisposition genes can be expected, and re cent data support such expectations. Paradoxically, however, when practicing clinical cancer genetics, familiality can still be presumed in all HBC as a whole. Bayesian calculations are still used to predict inheritance and cancer risk.

\section{Cancer Risk in Mutation-Positive Individuals}

Both MEN 2 and HBC are believed to have age-related penetrance (Ponder et al. 1988; Easton et al. 1993). Based on clinical presentation only, $70 \%$ of presumed RET mutation carriers will develop a sign or symptom by the age of 70 (Easton et al. 1989). Biochemical screening increases the penetrance figures to $95 \%$ by the age of 35 (Easton et al. 1989). Hence, in general, carriers of germ-line RET mutations have a high risk of developing MTC, PC, or HPT.

Based on the original linkage studies in large, exaggerated families with HBC, risk estimates for breast and/or ovarian cancer reached $85 \%-90 \%$ by the age of 70 and $50 \%$ by the age of 50 (Easton et al. 1993). A novel way of studying penetrance "in the field" is to perform a population-based estimate. Of course, this can be done only when the prevalence is reasonable. Such a study, which polled a large group of the Ashkenazim in the Washington, D.C. area, was performed to determine the penetrance of breast, ovarian, and prostate cancer among carriers of one of the three ancient BRCA1 mutations (Streuewing et al. 1997). The investigators concluded that the risk of developing breast, ovarian, or prostate cancers in mutation carriers by the age of 70 was $56 \%, 16 \%$, and $16 \%$, respectively. Previous estimates for the general population were as high as $85 \%, 40 \%$, and $15 \%$, respectively. This latest study, however, calculated penetrance based on questionnaire family histories. Clinical cancer geneticists will tell us 
Table 2. Hereditary Breast Cancer Syndromes

\begin{tabular}{ll}
\hline Syndrome & Known susceptibility gene(s) \\
\hline Site-specific breast cancer & BRCA1, BRCA2 \\
Site-specific ovarian cancer & BRCA1 \\
Breast-ovarian cancer & BRCA1,BRCA2 \\
Cowden syndrome & PTEN \\
Li-Fraumeni syndrome & p53 \\
HNPCC (Lynch syndrome) & hMSH2,hM LH1,hPM S2 \\
\hline
\end{tabular}

that patient-based family histories, especially of cancers in the abdomen and pelvis, are unreliable. Penetrance is a result of several factors, possibly including the nature and position of a mutation (Gayther et al. 1995, 1997), the modulating effects of other loci, and environmental exposure, all of which we really do not understand well. I suspect that the true penetrance of these three ancient mutations is probably not as high as previous estimates for the general non-Ashkenazim mutation carriers but somewhere in between.

\section{Effective Surveillance and Prophylaxis}

It is generally accepted that both prophylactic surgery (prophylactic thyroidectomy) and surveillance for component tumors for those at risk for MEN 2 are effective and life saving (Wells et al. 1994). The standard of care in MEN 2 is to perform routine RET mutation analysis as a clinical test. No prophylactic thyroidectomy should be performed without proof of the presence of the familyspecific mutation in an at-risk individual.

How about in HBC? Surveillance of the breasts and ovaries in at-risk individuals is recommended-but primarily because none dare to do otherwise. This recommendation is not based on direct evidence, only on extrapolations from population-based screening studies. Multiple studies have shown the benefit of mammography in the female population-at-large over the age of 50. Controversy continues concerning the efficacy of screening younger women. There has never been a population-based study proving that ovarian screening is effective. These negatives are likely attributable to the low prevalence of the disease being screened in the general population. Many screen women in high-risk families only because the prevalance of cancer in these families is much higher than in the general population; hence, the efficacy of screening should be evident. Hard evidence, however, is still lacking.

What of prophylactic surgery? From limited family studies, such surgery likely decreases the risk of breast and ovarian cancers, but by how much is unknown. It certainly does not decrease the risks to population levels. Obviously, randomized trials are not possible. Hence, to help surmount this problem, decision analysismodeling has been employed (Schrag et al. 1997). Modeled "numbers" are obtained: years gained, lives saved, and so on. However, these sorts of analyses and conclusions must be approached with great caution on the part of the public and clinicians (Healey 1997).

\section{Concluding Remarks}

By all counts, RET mutation analysis in MEN 2 meets all the criteria outlined in Table 1: No wonder it took only 6 months from publication (Mulligan et al. 1993) to routine clinical testing. But HBC is not MEN 2-so, what do we do now? Sometimes, the best action is ... inaction. Tongue in cheek aside, however, uncertainty does not mean that we should do nothing: In the long tradition of the art of medicine, it behooves the clinician to practice and advise to the best of his/her ability given the knowledge of the day-and the knowledge grows day by day. The clinician should not view cancer genetics as a strange beast either: The apparently decreasing frequency of BRCA1 mutations in HBC each time a study is performed is no dif- ferent from phase I-II chemotherapeutic trials yielding phenomenally high re sponse rates for metastatic cancer only to be dashed by phase III trials. The parallels continue: Patients chosen for phase I-II trials are stringently selected with narrow eligibility criteria just as much as the first studies on HBC targeted the most obvious, large families with multiple-affected individuals. Clinical cancer genetics as a burgeoning field where routine gene testing is performed to affect management decisions is at hand. To help it along, however, more, and not less genome-based research is required.

\section{ACKNOWLEDGMENTS}

I thank Kathy Schneider, Stephanie Kieffer, and Jan Vijg for critical review of the manuscript and/or helpful discussions. I am deeply grateful to Bruce Ponder for training me in clinical cancer genetics in all its nuances, and to Richard Kolodner and David Livingston for their support. C.E. is the Lawrence and Susan Marx Investigator in Human Cancer Genetics and is funded by the American Cancer Society (RPG-97-064-01 VM), the Harvard Nathan Shock Center of Excellence Award in the Basic Biology of Aging (1P30AG13314-01), the Markey Charitable Trust, the Charles A. Dana Foundation, and the Women's Cancer Program, Dana-Farber Partners Cancer Center.

\section{REFERENCES}

Borst, M.J., J.M. van Camp, M.L. Peacock, and R.A. Decker. 1995. Surgery 117: 386-389.

Couch, F.J., M.L. DeShano, M.A. Blackwood, K. Calzone, J. Stopfer, L. Campeau, A. Ganguly, T. Rebbeck, and B.L. Weber. 1997. N. Engl. J. Med. 336: 1409-1415.

Easton, D.F., D.T. Bishop, D. Ford, G.P. Crockford, and B.C.L. Consortium. 1993. Am. J. Hum. Genet. 52: 678-701.

Easton, D.F., M.A. Ponder, T. Cummings, R.F. Gagel, H.H. Hansen, S. Reichlin, A.H. Tashjian, M. Telenius-Berg, B.A.J. Ponder, and C.M.T. Group. 1989. Am. J. Hum. Genet. 44: 208-215.

Eng, C. 1996. N. Engl. J. Med. 335: 943-951.

Eng, C. and J. Vijg. 1997. Nature Biotechnol. 15: 422-426.

Eng, C., M. Stratton, B. Ponder, V. Murday, D. 


\section{Insight/Outlook}

Easton, N. Sacks, M. Watson, and R. Eeles. 1994. Lancet 343: 709-713.

Eng, C., D. Clayton, I. Schuffenecker, G. Le noir, G. Cote, R.F. Gagel, H.K. Ploos van Amstel, C.J.M. Lips, I. Nishisho, S.-I. Takai, D.J. Marsh, B.G. Robinson, K. Frank-Raue, F. Raue, F. Xue, W.W. Noll, C. Romei, F. Pacini, M. Fink, B. Niederle, J. Zedenius, M. Nordenskjöld, P. Komminoth, G.N. Hendy, H. Gharib, S.N. Thibodeau, A. Lacroix, A. Frilling, B.A.J. Ponder, and L.M. Mulligan. 1996. J. Am. Med. Assoc. 276: 1575-1579.

Gayther, S.A., W. Warren, S. Mazoyer, P.A. Russell, P.A. Harrington, M. Chiano, S. Seal, R. Hamoudi, E.J. van Rensburg, A.M. Dunning, R. Love, G. Evans, D. Easton, D. Clayton, M.R. Stratton, and B.A.J. Ponder. 1995. Nature Genet. 11: 428-433.

Gayther, S.A., J. Mangion, P. Russell, S. Seal, R. Barfoot, B.A.J. Ponder, M.R. Stratton, and D. Easton. 1997. Nature Genet. 15: 103-105.

Hall, J.M., M.K. Lee, J. Morrow, B. Newman, L. Anderson, B. Huey, and M.C. King. 1990. Science 250: 1684-1689.

Healey, B. 1997. N. Engl. J. Med. 336: 14481449.

Kambouris, M., C.E. Jackson, and G.L. Feldman. 1996. Hum. Mutat. 8: 64-70.

Liaw, D., D.J. Marsh, J. Li, P.L.M. Dahia, S.I. Wang, Z. Zheng, S. Bose, K.M. Call, H.C. Tsou, M. Peacocke, C. Eng, and R. Parsons. 1997. Nature Genet. 16: 64-67.

Marsh, D.J., B.G. Robinson, S. Andrew, A.-L. Richardson, R. Pojer, M. Schnitzler, L.M. Mulligan, and V.J. Hyland. 1994. Genomics 23: 477-479.

Miki, Y., J. Swensen, D. Shattuck-Eidens, P.A. Futreal, K. Harshman, S. Tavtigian, Q. Liu, C. Cochran, L.M. Bennett, W. Ding, R. Bell, J. Rosenthal, C. Hussey, T. Tran, M. McClure, C. Frye, T. Hattier, R. Phelps, A. Haugen-Strano, H. Katcher, K. Yakumo, Z. Gholami, D. Shaffer, S. Stone, S. Bayer, C. Wray, R. Bogden, P. Dayananth, J. Ward, P. Tonin, S. Narod, P.K. Bristow, F.H. Norris, L. Helvering, P. Morrison, P. Rosteck, M. Lai, J.C. Barrett, C. Lewis, S. Neuhausen, L. Cannon-Albright, D. Goldgar, R. Wiseman, A. Kamb, and M.H. Skolnick. 1994. Science 266: 66-71.

Mulligan L.M., J.B.J. Kwok, C.S. Healey, M.J. Elsdon, C. Eng, E. Gardner, D.R. Love, S.E. Mole, J.K. Moore, L. Papi, M.A. Ponder, H. Telenius, A. Tunnacliffe, and B.A.J. Ponder. 1993. Nature 363: 458-460.

Mulligan, L.M., C. Eng, C.S. Healey, D. Clayton, J.B.J. Kwok, E. Gardner, M.A. Ponder, A.
Frilling, C.E. Jackson, H. Lehnert, H.P.H. Neumann, S.N. Thibodeau, and B.A.J. Ponder. 1994. Nature Genet. 6: 70-74.

Myers, S.M., C. Eng, B.A.J. Ponder, and L.M. Mulligan. 1995. Oncogene 11: 2039-2045.

Nelen, M.R., G.W. Padberg, E.A.J. Peeters, A.Y. Lin, B. van den Helm, R.R. Frants, V. Coulon, A.M. Goldstein, M.M.M. van Reen, D.F. Easton, R.A. Eeles, S. Hodgson, J.J. Mulvihill, V.A. Murday, M.A. Tucker, E.C.M. Mariman, T.M. Starink, B.A.J. Ponder, H.H. Ropers, H. Kremer, M. Longy, and C. Eng. 1996. Nature Genet. 13: 114-116.

Ponder, B.A.J., M.A. Ponder, R. Coffey, M. Pembrey, R.F. Gagel, M. Telenius-Berg, P. Semple, and D.F. Easton. 1988. Lancet i: 397400.

Savitsky, K., S. Sfez, D.A. Tagle, Y. Ziv, A. Sartiel, F.S. Collins, Y. Shiloh, and G. Rotman. 1995. Hum. Mol. Genet. 4: 2025-2032.

Schrag D., K.M. Kuntz, J.E. Garber, and J.C. Weeks. 1997. N. Engl. J. Med. 336: 14651471.

Stoppa-Lyonnet, D., P. Laurent-Puig, L. Essioux, S. Pagès, G. Ithier, L. Ligot, A. Fourquet, R.J. Salmon, K.B. Clough, P. Pouillart, I.C.B.C. Group, C. Bonaiiti-Pellié, and G. Thomas. 1997. Am. J. Hum. Genet. 60: 1021-1030.

Streuewing, J.P., P. Hartge, S. Wacholder, S.M Baker, M. Berlin, M. McAdams, M.M. Timmerman, L.C. Brody, and M.A. Tucker. 1997. N. Engl. J. Med. 336: 1401-1408.

Tonin, P., B. Weber, K. Offit, F. Couch, T.R. Rebbeck, S. Neuhausen, A.K. Godwin, M. Daly, J. Wagner-Costalos, D. Berman, G. Grana, E. Fox, M.F. Kane, R.D. Kolodner, M. Krainer, D.A. Haber, J.P. Struewing, E. Warner, B. Rosen, C. Lerman, B. Peshkin, L. Norton, O. Serova, W.D. Foulkes, H.T. Lynch, G.M. Lenoir, S.A. Narod, and J.E. Garber. 1996. Nature Med. 2: 1179-1183.

Wells, S.A., D.D. Chi, D. Toshima, L.P. De hner, C.M. Coffin, B. Darton, J.L. Ivanovich, M.K. DeBenedetti, W.G. Dilley, J.F. Moley, J.A. Norton, and H. Donis-Keller. 1994. Ann. Surg. 200: 237-250.

Wooster, R., S.L. Neuhausen, J. Mangion, Y. Quirk, D. Ford, N. Collins, K. Nguyen, S. Seal, T. Tran, D. Averill, P. Fields, G. Marshall, S. Narod, G.M. Lenoir, H. Lynch, J. Feunteun, P. Devilee, C.J. Cornelisse, F.H. Menko, P.A. Daly, L.A. Cannon-Albright, J. Peto, B.A.J. Ponder, M.H. Skolnick, D.F. Easton, D.E. Goldgar, and M.R. Stratton. 1994. Science 265: 2088-2090.

Wooster, R., G. Bignell, J. Lancaster, S. Swift,
S. Seal, J. Mangion, N. Collins, S. Gregory, C. Gumbs, G. Mickiem, R. Barfoot, R. Hamoudi, S. Patel, C. Rice, P. Biggs, Y. Hashim, A. Smith, F. Connor, A. Arason, J. Gudmundsson, D. Ficenan, D. Kelsell, D. Ford, P. Tonin, D.T. Bishop, N.K. Spurr, B.A.J. Ponder, R. Eeles, J. Peto, P. Devilee, C. Cornelisse, H. Lynch, S. Narod, G. Lenoir, V. Egilsson, R.B. Barkadottir, D.F. Easton, D.R. Bentley, P.A. Futreal, A. Ashworth, and M.R. Stratton. 1995. Nature 378: 789-792. 


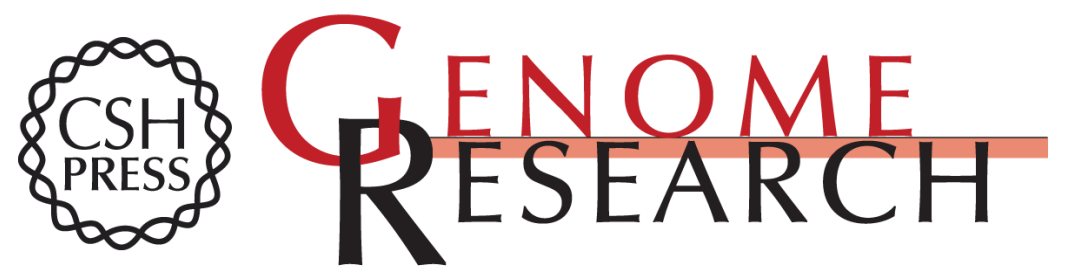

\section{QTL Mapping to QTL Cloning: Mice to the Rescue}

Michel Georges

Genome Res. 1997 7: 663-665

Access the most recent version at doi:10.1101/gr.7.7.663

References This article cites 12 articles, 4 of which can be accessed free at:

http://genome.cshlp.org/content/7/7/663.full.html\#ref-list-1

\section{License}

Email Alerting Receive free email alerts when new articles cite this article - sign up in the box at the Service top right corner of the article or click here.

\section{Affordable, Accurate Sequencing.}

To subscribe to Genome Research go to: https://genome.cshlp.org/subscriptions 